\title{
Ekstraksi Ciri pada Citra Iris Menggunakan Gabor 2-D
}

\author{
I Gusti Ayu Agung Diatri Indradewi ${ }^{1}$, I Putu Agung Bayupati ${ }^{2}$, I Ketut Gede Darma Putra ${ }^{3}$
}

\begin{abstract}
Iris is one of the parts of the human body that is often used in biometric recognition systems because it has high level of distinction. The difference is even found in the iris of the left and right of the same individual. Feature extraction is one of the stages in the development of iris biometric recognition system. The stage aims to extract the information from segmented iris image so it can be used as a unique characteristic of the iris. In this paper, the feature extraction stage is done using 2-D Gabor filter and the size of normalized iris is $50 \times 20$ pixel. The filter is used because it is able to provide the optimal combined representation of signals in spatial and frequency domain. The results of the implementation of 2-D Gabor filter are demodulated by using 2-D Gabor quadrature to generate the iris code used as an iris information criterion (characteristic features). The result produced the best iris feature when the size of the filter used is $33 \times 33$. The orientation angle used for real and imaginary feature are $45^{\circ}, 0^{\circ}, 45^{\circ}$, dan $90^{\circ}$.
\end{abstract}

Intisari- Iris merupakan salah satu bagian tubuh manusia yang sering digunakan dalam sistem pengenalan biometrik karena tingkat perbedaan yang tinggi antara iris yang satu dengan iris lainnya. Perbedaan ini bahkan terdapat pada iris kiri dan kanan dari individu yang sama. Ektraksi ciri merupakan salah satu tahapan yang dilalui dalam pengembangan sistem pengenalan biometrik iris. Tahap ini bertujuan untuk mengekstrak informasi dari citra iris yang telah disegmentasi sehingga dapat digunakan sebagai ciri unik dari iris bersangkutan. Pada paper ini tahap ekstraksi ciri dilakukan dengan menggunakan tapis Gabor 2-D. Citra yang digunakan merupakan hasil normalisasi terhadap wilayah iris yang berukuran $50 \times 20$ piksel. Tapis tersebut digunakan karena mampu menyediakan representasi gabungan yang optimal dari sinyal dalam domain spasial dan frekuensi. Hasil penerapan tapis Gabor 2-D didemodulasi dengan menggunakan quadrature Gabor 2-D untuk menghasilkan iris code yang dijadikan sebagai informasi pembeda (fitur ciri) iris. Hasil uji coba pada penelitian ini menghasilkan fitur iris terbaik ketika ukuran tapis yang digunakan adalah $33 \times 33$. Sudut orientasi yang digunakan untuk fitur real dan imaginary adalah $-\mathbf{4 5}^{\circ}, 0^{\circ}, 4^{\circ}$, dan $90^{\circ}$.

Kata Kunci-Gabor 2-D, fitur real, fitur imaginary, iris code.

\section{PENDAHULUAN}

Sistem pengenalan biometrik menggunakan karakteristik fisiologis atau karakteristik perilaku untuk mengenali identitas seseorang. Karakteristik fisiologis adalah ciri fisik yang relatif stabil seperti sidik jari, geometri tangan, pola iris, dan retina. Sedangkan karakteristik perilaku, seperti tanda tangan, pola ucapan, atau ritme mengetik, selain memiliki basis fisiologis yang relatif stabil, juga dipengaruhi kondisi psikologis yang mudah berubah.

\footnotetext{
${ }^{1}$ Mahasiswa, Magister Teknik Elektro Universitas Udayana, Gedung Pascasarjana Universitas Udayana Jl. PB Sudirman Denpasar-Bali $80232 \quad$ (tlp/fax: 0361-239599; e-mail: didyrakata@gmail.com)

${ }^{2,3}$ Dosen Magister Teknik Elektro Universitas Udayana, Gedung Pascasarjana Universitas Udayana Jl. PB Sudirman Denpasar-Bali 80232 (tlp/fax:0361-239599; e-mail: bayuhelix@yahoo.com)
}

Iris merupakan salah satu karakteristik fisiologis manusia yang memiliki tingkat akurasi tinggi karena iris memiliki struktur fisik yang kaya sehingga dapat menyediakan banyak data [1]. Untuk mengekstrak data tersebut dalam pengembangan sistem pengenalan biometrik terdapat tahap ekstraksi ciri. Tahap ini bertujuan untuk mengekstrak informasi dari citra iris yang telah disegmentasi sehingga dapat digunakan sebagai ciri unik dari iris bersangkutan.

Dalam hal ekstraksi ciri, tapis Gabor telah sukses diaplikasikan pada banyak aplikasi pengenalan pola. Salah satu hal yang menyebabkan tapis Gabor banyak digunakan adalah karena frekuensi dan representasi orientasi dari tapis Gabor mirip dengan sistem visual manusia. Selain itu tapis Gabor sangat sesuai untuk representasi dan diskriminasi tekstur.

Penelitian yang berkaitan dengan penggunaan tapis Gabor 2-D terus bermunculan dalam berbagai bidang aplikasi. Pada [2], tapis Gabor 2-D digunakan untuk mengkonstruksi himpunan fitur iris. Untuk merepresentasikan informasi tekstur lokal dan global, ketidaksamaan dihitung berdasarkan multi-directional Gabor untuk setiap iris. Pada [3], tapis Gabor 2-D digunakan untuk mendeteksi ada tidaknya cacat pada kulit buah. Pada [4], tapis Gabor 2-D digunakan untuk deskripsi dan ekstraksi fitur tekstur pada kulit wajah dan citra kulit medis.

Berdasarkan pemaparan tersebut, dalam paper ini tapis Gabor 2-D digunakan untuk mengekstrak fitur ciri pada citra iris. Permasalahan yang menjadi topik utama dalam paper ini terkait dengan penggunaan tapis Gabor 2-D pada ekstraksi ciri adalah mengenai pemilihan ukuran tapis Gabor 2-D yang dapat menghasilkan fitur iris terbaik yang mengandung lebih banyak variasi tekstur.

\section{BIOMETRIK IRIS}

Iris adalah daerah berbentuk gelang pada mata yang dibatasi oleh pupil (bagian pusat mata yang berwarna hitam) dan sclera (bagian putih dari mata). Tekstur visual dari iris seperti yang ditampilkan pada Gambar 1 dibentuk selama perkembangan janin di dalam kandungan dan selanjutnya tekstur tersebut menstabilkan diri sepanjang dua tahun pertama kehidupan janin tersebut di luar kandungan (setelah lahir). Tekstur iris yang kompleks mengandung informasi yang bersifat sangat unik dan dapat dimanfaatkan untuk pengenalan individu [5].

Pengenalan terhadap identitas seseorang pada sistem biometrik dilakukan secara otomatis berdasarkan suatu ciri biometrik dengan cara mencocokkan ciri tersebut dengan ciri biometrik yang telah disimpan dalam database. Sebagai suatu sistem otentikasi, sistem biometrik akan menghasilkan keputusan dari hasil pengenalan/pencocokan yang diperoleh berupa sah atau tidak sah, diterima atau ditolak, dan dikenali atau tidak dikenali. Terdapat beberapa proses penting yang harus dilakukan dalam membangun suatu sistem pengenalan biometrik iris. Proses-proses tersebut terdiri dari akuisisi citra iris, segmentasi iris, ekstraksi ciri, dan pencocokkan ciri [5]. 


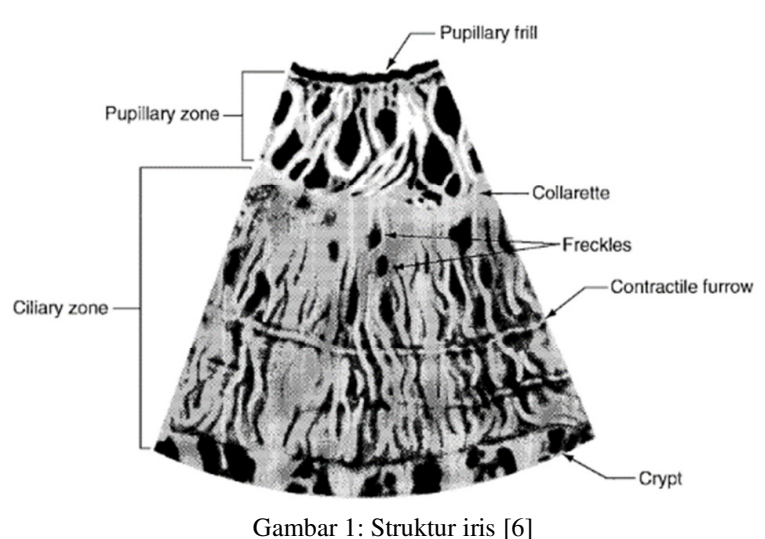

III. EKSTRAKSI CIRI

Ekstraksi ciri (feature extraction) merupakan bagian fundamental dari analisis citra. Fitur adalah karakteristik unik dari suatu objek. Karakteristik fitur yang baik sebisa mungkin memenuhi persyaratan berikut [5]:

1. Dapat membedakan suatu objek dengan yang lainnya (discrimination).

2. Memperhatikan kompleksitas komputasi dalam memperoleh fitur. Kompleksitas komputasi yang tinggi akan menjadi beban tersendiri dalam menemukan suatu fitur.

3. Tidak terikat (independence) dalam arti bersifat invarian terhadap berbagai transformasi (rotasi, penskalaan, pergeseran, dan lain sebagainya).

4. Jumlahnya sedikit, karena fitur yang jumlahnya sedikit akan dapat menghemat waktu komputasi dan ruang penyimpanan untuk proses selanjutnya (proses pemanfaatan fitur).

Pada sistem pengenalan biometrik iris, tahap ekstraksi ciri bertujuan untuk mengekstrak informasi dari citra iris yang telah dipetakan ke koordinat polar sehingga dapat digunakan sebagai ciri unik dari iris bersangkutan. Semakin tinggi variasi nilai dari fitur iris maka semakin unik fitur iris tersebut. Sehingga akan lebih mudah dibedakan antara iris yang satu dengan iris yang lain.

\section{A. Tapis Gabor 2-D}

Suatu kumpulan tapis Gabor dengan frekuensi dan orientasi berbeda berguna untuk mengekstrak fitur-fitur penting yang ada pada citra. Tapis Gabor 2-D diaplikasikan pada citra yang memiliki skala dan frekuensi berbeda. Bagian real dan imaginary dikonvolusi untuk membentuk citra hasil pentapisan.

Tapis Gabor 2-D dalam domain spasial dirumuskan dengan persamaan berikut [7]:

$G(x, y, \theta, u, \sigma)=\hat{g}(x, y) s(x, y)$

dengan $x$ dan $y$ merupakan koordinat dari tapis Gabor, $\theta$ merupakan kontrol terhadap orientasi dari fungsi Gabor, $u$

I Gusti Ayu Agung Diatri Indradewi : Ekstraksi Ciri pada Citra ... merupakan frekuensi dari gelombang sinusoidal, dan $\sigma$ merupakan standard deviasi dari gaussian envelope.

Persamaan (1) dibentuk dari dua komponen, yaitu gaussian envelope $(\hat{g}(x, y))$ yang ditunjukkan oleh (2) dan gelombang sinusoidal $(s(x, y))$ dalam bentuk kompleks yang ditunjukkan oleh (3).

$\hat{g}(x, y)=\frac{1}{2 \cdot \pi \cdot \sigma^{2}} \exp \left\{-\frac{x^{2}+y^{2}}{2 \sigma^{2}}\right\}$

$s(x, y)=\exp \{i(2 \cdot \pi(u \cdot x \cdot \cos \theta+u \cdot y \cdot \sin \theta))\}$

Dari dua komponen tersebut, maka diperoleh dua fungsi terpisah yang dinyatakan dengan bagian real dan imaginary.

Jika tapis Gabor dengan beragam frekuensi $(u)$ dan sudut orientasi $(\theta)$ diterapkan pada suatu titik tertentu pada citra, maka akan diperoleh banyak respon tapis untuk titik tersebut sesuai dengan jumlah frekuensi dan sudut orientasi yang digunakan. Setiap respon tapis yang dihasilkan dikonvolusi dengan citra yang menjadi objek ekstraksi ciri. Hasil konvolusi akan memunculkan fitur-fitur tertentu yang merupakan karakteristik citra. Fitur-fitur tersebut terdiri dari bagian real dan imaginary berdasarkan (2) dan (3).

\section{METODE}

\section{A. Preprocessing}

Proses segmentasi merupakan proses yang dilakukan sebelum masuk ke tahap ekstraksi ciri. Proses ini bertujuan untuk mendapatkan wilayah iris yang sudah terpisah dari pupil, kelopak mata, dan bagian putih mata (sclera). Wilayah iris memiliki batas dalam dan batas luar. Batas dalam iris adalah batas yang memisahkan pupil dengan iris. Sedangkan batas luar iris adalah batas yang memisahkan iris dengan sclera. Kedua batas tersebut dihasilkan dalam bentuk himpunan koordinat. Himpunan koordinat batas dalam dan luar iris yang membentuk wilayah iris selanjutnya dinormalisasi untuk mengubah sistem koordinat batas-batas iris yang dihasilkan dari koordinat kartesian ke koordinat polar. Dalam hal ini, wilayah iris dimodelkan sebagai lembaran karet fleksibel yang dikaitkan pada batas iris dengan titik pusat pupil sebagai titik acuan. Sejumlah titik dipilih di sepanjang garis radial dan disebut sebagai resolusi radial $(\rho)$. Jumlah garis radial di sekitar wilayah iris disebut resolusi angular $(\theta)$. Dari wilayah iris yang menyerupai donat, normalisasi menghasilkan array 2- $D$ dengan dimensi horizontal dari resolusi angular dan dimensi vertikal dari resolusi radial.

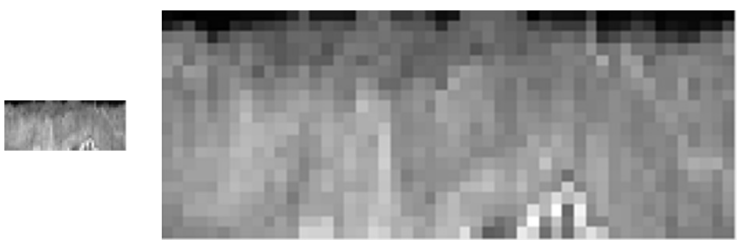

(a)

(b)

Gambar 2: Normalisasi wilayah iris ke koordinat polar (a) ukuran $50 \times 20$ piksel (b) ukuran diperbesar menjadi $200 \times 80$ piksel

p-ISSN:1693 - 2951; e-ISSN: 2503-2372 
Gambar 2 (a) menunjukkan hasil normalisasi wilayah iris dari koordinat kartesian ke koordinat polar. Citra hasil normalisasi yang dihasilkan berukuran $50 \times 20$ piksel. Pada Gambar 2 (b) ditampilkan hasil normalisasi wilayah iris yang telah diperbesar ke ukuran $200 \times 80$ piksel. Iris code selanjutnya dibentuk berdasarkan citra hasil normalisasi melalui proses ekstraksi ciri.

\section{B. Ekstraksi Ciri}

Tekstur merupakan salah satu fitur yang paling diskriminatif pada suatu iris. Informasi tekstur iris dapat direpresentasikan berdasarkan tapis Gabor 2-D melalui proses ekstraksi ciri. Ekstraksi ciri bertujuan untuk mengekstrak informasi dari citra iris yang telah dipetakan ke koordinat polar sehingga dapat digunakan sebagai ciri unik dari iris bersangkutan. Pentapisan dilakukan terhadap citra iris yang dihasilkan dari proses segmentasi, yakni berupa citra iris yang telah dipetakan ke koordinat polar.

Tapis Gabor 2-D dibentuk dalam bagian real dan imaginary. Tapis yang terbentuk dikonvolusi dengan citra iris yang telah dipetakan ke koordinat polar sehingga menghasilkan 4 fitur iris sesuai dengan nilai sudut orientasi $(\theta)$ yang digunakan. Hasil konvolusi yang telah dipisahkan berdasarkan bagian real dan imaginary dibentuk menjadi iris code.

Pembentukan iris code pada bagian real dilakukan berdasarkan ketentuan yang ditunjukkan oleh (4) dan (5).

$$
\begin{aligned}
& b r=1 \text { if } \operatorname{Re}[\tilde{G}[x, y, \theta, \sigma] * I] \geq 0 \\
& b r=0 \text { if } \operatorname{Re}[\tilde{G}[x, y, \theta, \sigma] * I]<0
\end{aligned}
$$

Bagian real dari hasil konvolusi tapis Gabor 2-D dengan citra iris disimbolkan dengan $\operatorname{Re}[\tilde{G}[x, y, \theta, \sigma] * I]$.

Pembentukan iris code pada bagian imaginary dilakukan berdasarkan ketentuan yang ditunjukkan oleh (6) dan (7).

$$
\begin{aligned}
& b i=1 \text { if } \operatorname{Im}[\tilde{G}[x, y, \theta, \sigma] * I] \geq 0 \\
& b i=0 \text { if } \operatorname{Im}[\tilde{G}[x, y, \theta, \sigma] * I]<0
\end{aligned}
$$

Bagian imaginary dari hasil konvolusi tapis Gabor 2-D dengan citra iris disimbolkan dengan $\operatorname{Im}[\tilde{G}[x, y, \theta, \sigma] * I]$.

\section{HASIL DAN PEMBAHASAN}

\section{A. Hasil}

Pada paper ini, data citra yang digunakan adalah citra iris MMU Iris Database yang dimiliki oleh Multimedia University Malaysia seperti yang ditunjukkan pada Gambar 3. Seluruh citra pada data set tersebut merupakan citra grayscale 24 bit dengan format BMP dan berukuran $320 \times 240$ piksel. Citra MMU Iris Database merupakan citra grayscale 24 bit sehingga perlu dilakukan konversi untuk mengubahnya menjadi citra grayscale 8 bit untuk mempermudah prosesproses selanjutnya.

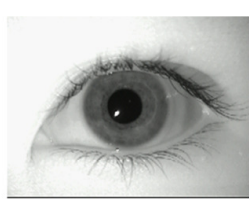

Gambar 3: Citra MMU Iris Database [8]

Percobaan dilakukan dengan membentuk tapis Gabor 2-D berukuran $9 \times 9,17 \times 17$, dan $33 \times 33$. Sudut orientasi $(\theta)$ yang digunakan adalah $90^{\circ}, 45^{\circ}, 0^{\circ}$, dan $-45^{\circ}$. Tapis-tapis yang terbentuk selanjutkan dikonvolusi dengan citra iris yang telah dipetakan ke koordinat polar. Hasil pembentukan tapis Gabor $2-D$ berukuran $9 \times 9$ pada bagian real ditampilkan pada Gambar 4. Sedangkan pada Gambar 5 ditampilkan hasil pembentukan tapis Gabor 2-D pada bagian imaginary.

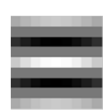

(a)

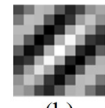

(b)

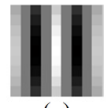

(c)

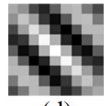

(d)
Gambar 4: Tapis Gabor 2-D bagian real berukuran $9 \times 9$ (a) $90^{\circ}$ (b) $45^{\circ}$ (c) $0^{\circ}$ (d) $-45^{\circ}$

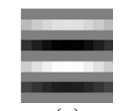

(a)

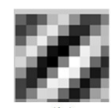

(b)

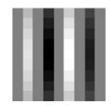

(c)

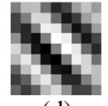

(d)
Gambar 5: Tapis Gabor 2-D bagian imaginary berukuran $9 \times 9$ (a) $90^{\circ}$ (b) $45^{\circ}$ (c) $0^{\circ}$ (d) $-45^{\circ}$

Hasil pembentukan tapis Gabor 2-D berukuran $17 \times 17$ pada bagian real ditampilkan pada Gambar 6. Sedangkan pada Gambar 7 ditampilkan hasil pembentukan tapis Gabor 2-D pada bagian imaginary.

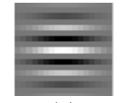

(a)

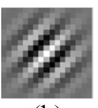

(b)

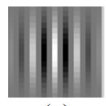

(c)

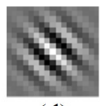

(d)
Gambar 6: Tapis Gabor 2-D bagian real berukuran $17 \times 17$ (a) $90^{\circ}$ (b) $45^{\circ}$ (c) $0^{\circ}(\mathrm{d})-45^{\circ}$

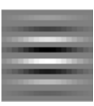

(a)

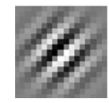

(b)

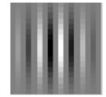

(c)

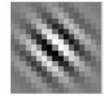

(d)
Gambar 7: Tapis Gabor 2-D hagian imaginary herukuran $17 \times 17$ (a) $90^{\circ}$ (b) $45^{\circ}(\mathrm{c}) 0^{\circ}(\mathrm{d})-45^{\circ}$

Hasil pembentukan tapis Gabor 2-D berukuran $33 \times 33$ pada bagian real ditampilkan pada Gambar 8. Sedangkan pada Gambar 9 ditampilkan hasil pembentukan tapis Gabor 2-D pada bagian imaginary.

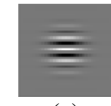

(a)

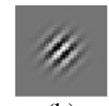

(b)

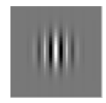

(c)

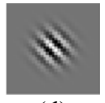

(d)
Gambar 8: Tapis Gabor 2-D bagian real berukuran $33 \times 33$ (a) $90^{\circ}$ (b) $45^{\circ}$ (c) $0^{\circ}$ (d) $-45^{\circ}$ 


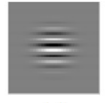

(a)

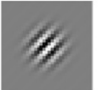

(b)

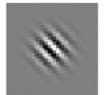

(c)

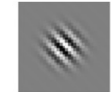

(d)
Gambar 9: Tapis Gabor 2- $D$ bagian imaginary berukuran $33 \times 33$ (a) $90^{\circ}$ (b) $45^{\circ}$ (c) $0^{\circ}$ (d) $-45^{\circ}$

\section{B. Pembahasan}

Gambar 10 menunjukkan fitur iris pada bagian real dengan menggunakan tapis berukuran $9 \times 9$. Pada Gambar 10 terlihat bahwa dengan menggunakan tapis berukuran $9 \times 9$, pola warna yang dominan pada keempat sudut orientasi fitur iris adalah putih (bernilai 1) dan terlihat terkonsentrasi pada bagian tertentu dari fitur iris sehingga variasi struktur iris code yang terbentuk sangat rendah. Hal ini disebabkan oleh nilai fitur iris pada bagian real yang merupakan hasil konvolusi dengan tapis Gabor 2-D lebih dominan menghasilkan nilai lebih besar dari 0 sehingga ketika pembentukan iris code dengan ketentuan (4) dan (5), iris code yang terbentuk didominasi oleh salah satu nilai yaitu 1 .

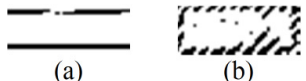

(b)
!

(c)

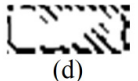

(d)
Gambar 10: Fitur iris bagian real dengan tapis berukuran $9 \times 9$ (a) $90^{\circ}$ (b) $45^{\circ}$ (c) $0^{\circ}$ (d) $-45^{\circ}$

Gambar 11 menunjukkan fitur iris pada bagian imaginary dengan menggunakan tapis berukuran $9 \times 9$. Pada Gambar 11 terlihat bahwa dengan menggunakan tapis berukuran $9 \times 9$, pola warna pada fitur iris (b), (c), dan (d) bervariasi antara hitam dan putih, tidak terlalu dominan pada salah satu warna tertentu. Hanya pada fitur iris (a), pada beberapa bagian warna yang dihasilkan masih dominan pada warna tertentu, yakni putih (bernilai 1) dan terlihat terkonsentrasi pada bagian tertentu dari fitur iris sehingga variasi struktur iris code yang terbentuk sangat rendah. Hal ini disebabkan oleh nilai fitur iris pada bagian imaginary yang merupakan hasil konvolusi dengan tapis Gabor 2-D lebih dominan menghasilkan nilai lebih besar dari 0 sehingga ketika pembentukan iris code dengan ketentuan (6) dan (7), iris code yang terbentuk didominasi oleh salah satu nilai yaitu 1 .

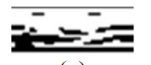

(a)

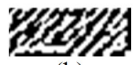

(b)

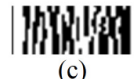

(c)

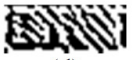

(d)
Gambar 11: Fitur iris bagian imaginary dengan tapis berukuran $9 \times 9$ (a) $90^{\circ}$ (b) $45^{\circ}$ (c) $0^{\circ}$ (d) $-45^{\circ}$

Gambar 12 menunjukkan fitur iris pada bagian real dengan menggunakan tapis berukuran $17 \times 17$. Pada Gambar 12 terlihat bahwa dengan menggunakan tapis berukuran $17 \times 17$, pola warna pada fitur iris (a), (b), dan (d) bervariasi antara hitam dan putih, tidak terlalu dominan pada salah satu warna tertentu. Hanya pada fitur iris (c), pada beberapa bagian warna yang dihasilkan masih dominan pada warna tertentu, yakni putih (bernilai 1) dan terlihat terkonsentrasi pada bagian tertentu dari fitur iris sehingga variasi struktur iris code yang terbentuk sangat rendah. Hal ini disebabkan oleh nilai fitur iris

I Gusti Ayu Agung Diatri Indradewi : Ekstraksi Ciri pada Citra ... pada bagian real yang merupakan hasil konvolusi dengan tapis Gabor 2-D lebih dominan menghasilkan nilai lebih besar dari 0 sehingga ketika pembentukan iris code dengan ketentuan (4) dan (5), iris code yang terbentuk didominasi oleh salah satu nilai yaitu 1 .

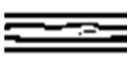

(a)

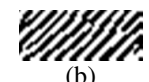

(b)

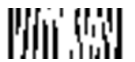

(c)

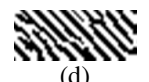

(d)
Gambar 12: Fitur iris bagian real dengan tapis berukuran $17 \times 17$ (a) $90^{\circ}$ (b) $45^{\circ}$ (c) $0^{\circ}$ (d) $-45^{\circ}$

Gambar 13 menunjukkan fitur iris pada bagian imaginary dengan menggunakan tapis berukuran $17 \times 17$. Pada Gambar 13 terlihat bahwa dengan menggunakan tapis berukuran $17 \times 17$, fitur iris (b), (c), dan (d) bervariasi antara hitam dan putih, tidak terlalu dominan pada salah satu warna tertentu. Hanya pada fitur iris (a), pada beberapa bagian warna yang dihasilkan masih dominan pada warna tertentu, yakni putih (bernilai 1) dan terlihat terkonsentrasi pada bagian tertentu dari fitur iris sehingga variasi struktur iris code yang terbentuk rendah. Hal ini disebabkan oleh nilai fitur iris pada bagian imaginary yang merupakan hasil konvolusi dengan tapis Gabor 2-D lebih dominan menghasilkan nilai lebih besar dari 0 sehingga ketika pembentukan iris code dengan ketentuan (6) dan (7), iris code yang terbentuk didominasi oleh salah satu nilai yaitu 1 .

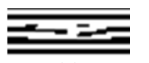

(a)

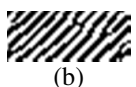

(b)

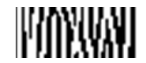

(c)

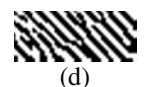

(d)
Gambar 13: Fitur iris bagian imaginary dengan tapis berukuran $17 \times 17$ (a) $90^{\circ}$ (b) $45^{\circ}$ (c) $0^{\circ}$ (d) $-45^{\circ}$

Gambar 14 menunjukkan fitur iris pada bagian real dengan menggunakan tapis berukuran $33 \times 33$. Pada Gambar 14 terlihat bahwa dengan menggunakan tapis berukuran $33 \times 33$, keempat fitur iris yang dihasilkan bervariasi antara hitam dan putih, tidak terlalu dominan pada salah satu warna tertentu sehingga terlihat keunikan dari setiap fitur iris. Hal ini disebabkan oleh nilai fitur iris pada bagian real yang merupakan hasil konvolusi dengan tapis Gabor 2-D menghasilkan nilai yang bervariasi, baik lebih besar dari 0 maupun kurang dari 0 sehingga ketika pembentukan iris code dengan ketentuan (4) dan (5), iris code yang terbentuk memiliki persebaran nilai 0 dan 1 yang lebih merata.

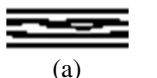

(a)

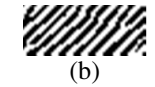

(b)

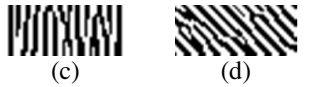

(c)
Gambar 14: Fitur iris bagian real dengan tapis berukuran $33 \times 33$ (a) $90^{\circ}$ (b) $45^{\circ}$ (c) $0^{\circ}(\mathrm{d})-45^{\circ}$

Gambar 15 menunjukkan fitur iris pada bagian imaginary dengan menggunakan tapis berukuran $33 \times 33$. Pada Gambar 15 terlihat bahwa dengan menggunakan tapis berukuran $33 \times 33$, keempat fitur iris yang dihasilkan juga bervariasi antara hitam dan putih, tidak terlalu dominan pada salah satu warna tertentu sehingga terlihat keunikan dari setiap fitur iris sama halnya seperti pada fitur iris bagian real. Hal ini disebabkan oleh nilai fitur iris pada bagian imaginary yang 
merupakan hasil konvolusi dengan tapis Gabor 2-D menghasilkan nilai yang bervariasi, baik lebih besar dari 0 maupun kurang dari 0 sehingga ketika pembentukan iris code dengan ketentuan (6) dan (7), iris code yang terbentuk memiliki persebaran nilai 0 dan 1 yang lebih merata.

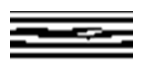

(a)

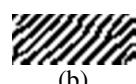

(b)

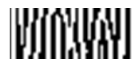

(c)

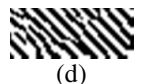

(d)
Gambar 15: Fitur iris bagian imaginary dengan tapis berukuran $33 \times 33$ (a) $90^{\circ}$ (b) $45^{\circ}$ (c) $0^{\circ}$ (d) $-45^{\circ}$

\section{KESIMPULAN}

Paper ini telah memaparkan penerapan tapis Gabor 2-D pada tahap ekstraksi ciri sehingga menghasilkan fitur ciri yang dapat digunakan sebagai ciri pembeda pada sistem pengenalan biometrik iris. Berdasarkan hasil percobaan yang diperoleh dapat disimpulkan bahwa semakin besar ukuran tapis yang digunakan, pola tekstur fitur iris yang dihasilkan memiliki persebaran nilai 0 dan 1 yang lebih merata, tidak dominan pada satu nilai saja. Ratanya persebaran nilai tersebut terlihat dari pola warna hitam (0) dan putih (1) yang ditampilkan pada Gambar 14 dan Gambar 15. Oleh karena itu tapis berukuran $33 \times 33$ lebih baik jika digunakan sebagai ciri pembeda pada setiap iris dengan ukuran citra iris ternormalisasi sebesar $50 \times 20$ piksel karena dengan persebaran nilai yang lebih merata dan tidak terkonsentrasi pada bagian tertentu fitur iris akan menghasilkan ciri unik yang mampu membedakan setiap iris dengan lebih baik.

\section{UCAPAN TERIMA KASIH}

Terima kasih penulis panjatkan kehadapan Ida Sang Hyang Widhi Wasa/Tuhan Yang Maha Esa, karena hanya atas asung wara nugraha-Nya/kurnia-Nya, paper ini dapat diselesaikan. Terima kasih juga penulis tujukan kepada Dr. Eng. Putu Agung Bayupati, S.T., M.T. selaku Pembimbing I dan Prof. Dr. I Ketut Darma Putra, S.Kom., M.T. selaku Pembimbing II yang telah membantu memberi masukan terhadap penulisan paper ini.

\section{REFERENSI}

[1] Rongnian Tang, Jiuqiang Han, Xinman Zhang, "Efficient Iris Segmentation Method With Support Vector Domain Description", Optica Applicata, Vol. 32, No. 2, 2009.

[2] Qi Wang, Xiangde Zhang, Mingqi Li, Xiaopeng Dong, Qunhua Zhou, Yu Yin, "Adaboost and Multi-Orientation 2D Gabor-based Noisy Iris Recognition", Pattern Recognition Letters, Vol. 33, pp. 978-983, 2012.

[3] Deepesh Kumar Srivastava, "Efficient Fruit Defect Detection and Glare Removal Algorithm by Anisotropic Diffusion and 2D Gabor Filter", International Journal of Engineering Science \& Advanced Technology, Vol. 2, No. 2, pp. 352-357, 2012.

[4] Xiang Ou, Ji Li, Wei Pan, Xu Zhang, Perry Xiao, "Content-based Image Retrieval using 2D Gabor Wavelet Texture Feature", Cosmetics, Vol. 1, pp. 1-11, 2013.

[5] Darma Putra, Pengolahan Citra Digital,Yogyakarta, Andi Offset, 2010 .

[6] Wildes, Richard P.. 1997. "Iris Recognition: An Emerging Biometric Technology". Proceedings of The IEEE, 85(9), p.1348-1363.

[7] Darma Putra, Sistem Biometrika, Yogyakarta, Andi Offset, 2009.

[8] MMU Iris Database: http://pesona.mmu.edu.my/ ccteo. 